SDI

\title{
Japan eager to join in the star wars fray
}

Tokyo

JAPAN is sailing steadily towards taking part in the US Strategic Defense Initiative (SDI), and the opposition that was expected to wreck participation has altogether failed to materialize. At the end of this week, 46 representatives and engineers from 21 of Japan's high-technology companies, accompanied by nine government officials, will set off to the United States for a 10-day tour of institutes and companies where SDI research is taking place. This is the first time that industry has been involved in SDI missions to the United States, and completes the groundwork for industrial participation.

Executives of high-technology companies are already happy to admit that they have been contacted by government officials encouraging them to look for SDI contracts. What is worrying industry now is not whether they will be allowed to participate but, as the head of one small electronics company put it, "the extent to which the government is intending to try to control affairs from behind the scenes".

Keeping direct government involvement, and research in government laboratories, out of sight looks like the last concession that will be made to those who oppose SDI. So far, the opposition has in any case been remarkable for its silence. Neither the principal opposition parties nor the media have attempted to make a major political issue out of SDI, despite the extremely emotive nature of defence issues in Japan.

One reason is that the opposition has much bigger problems to think about. In the next few months, Prime Minister Yasuhiro Nakasone will begin the breakup of the state-owned Japan National Railways (JNR) into six regional private companies, plus companies to run the "bullet" train and freight services. The aim is to get JNR's almost unbelievable debt - in excess of the foreign debt of Mexico - off the public shoulders and to shed almost 40 per cent of its third of a million staff. The principal opposition party, the Japan Socialist Party, and the unions have enough to do opposing privatization without worrying about SDI.

Opposition to SDI participation may also arise through factional struggles within the ranks of Nakasone's own Liberal Democratic Party (LDP). The Prime Minister seems clearly to be aiming at calling elections for both upper and lower houses of the Diet in June. At that time, he should be at the peak of his popularity. He will have visited the United States in April and hosted the summit of industrial nations in Tokyo in June, both of which are certain to heighten his image as Japan's first truly international statesman. If a resounding victory in the elections follows, he will be in a position to call for a change in the LDP rules that will allow him to stay on for a third two-year term as LDP leader, and thus Prime Minister.

Naturally enough, other contenders for the LDP leadership who now begin to see that the end of Nakasone's fixed term of

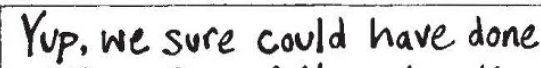
with a few of those beauties above Pearl Harbor...

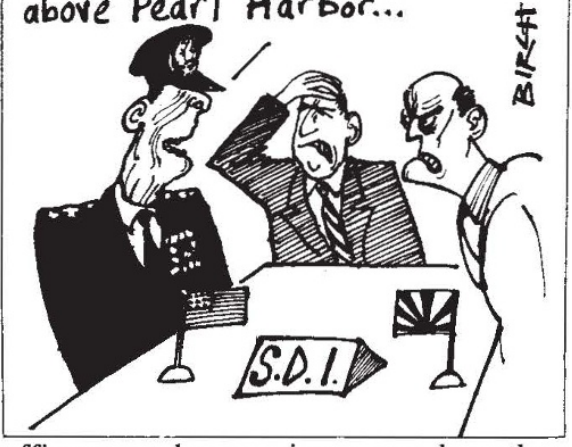

office may be a mirage are less than happy. Among them, Foreign Minister Shintaro Abe is known to be cool towards SDI participation: so internal feuds within LDP could still lead to a change of course.

The only other serious barrier to participation is a 199 all-party Diet resolution banning the military use of space. The resolution has been taken seriously and has been invoked, for example, to try to stop the self-defence forces using Japanese-launched commercial satellites for military communications. But lawyers already believe that loopholes can be found.

Next week's mission to the United States is plainly aimed at looking for commercial possibilities. It will include engineers from virtually all of Japan's big electronics companies - Fujitsu, Hitachi, NEC, Sony, Oki and Sumitomo - as well as from large self-defence force contractors such as Mitsubishi Heavy Industries. The industrial representatives will split into three groups according to their fields of commercial expertise. They will visit the Lincoln Laboratory of MIT, the Los Alamos National Laboratory and the US Army Strategic Defense Command as well as several industrial companies.

Worries that Japan's lack of antiespionage laws might limit participation seem also to have been dispelled. US Defense Secretary Caspar Weinoerger said last week that Japan would not have to be bound by special confidentiality agreements to carry out SDI research, given the "high level of trust between the two nations"

At the end of the day, however, there is still no doubt that many researchers in industry would prefer to have little to do with SDI. Some, who remember the Second World War, find any involvement with the military regrettable. Others attribute Japan's economic miracle to its refusal to waste talent or money on the development of military rather than consumer technology. They fear they are gradually going to be dragged down into the same hole in which the United States finds itself.

\section{Waving the star (wars) and stripes}

\section{Washington}

No expense was spared, no detail too small at a Washington banquet and award ceremony held last week for heroes of the Strategic Defense Initiative (SDI). Even jaded regulars at defence contractor bashes were flabbergasted when a full-colour guard in revolutionary war uniforms marched to the podium to the beat of fife and drum, bearing the stars and stripes and military flags festooned with campaign streamers.

The Hollywood-style ceremony was held by the American Defense Preparedness Association (ADPA), a defence contractor organization, as part of a two-day classified symposium on SDI at the National Academy of Sciences. The first two recipients of the ADPA Strategic Defense Award were Dr James Fletcher, recently nominated as administrator of the National Aeronautics and Space Administration and chairman of a key early study that supported SDI, and Dr George Keyworth, a fervent SDI advocate who was until recently director of the White House's Office of Science and Technology Policy. Medallions bearing the ADPA seal were presented to the proud winners by no less than Lt General James Abrahamson, director of the SDI organization.

Banquet guests were then treated to fiveminute film clips capturing dramatic highpoints of the public-consumption experiment spectaculars. The US Army's SDI team and the Lockheed Missile and Space Company took home the ADPA Strategic Defense Technical Achievement Award, for the successful homing overlay experiment in which a dummy missile was intercepted and destroyed in space. Runners-up were Dr Richard Briggs of Lawrence Livermore Laboratory (free electron laser), and Itek Optical Systems Division (atmospheric compensation system, tested on television during a shuttle flight last year).
Tim Beardsley 